\title{
14. CHEMISTRY OF INTERSTITIAL WATERS SAMPLED DURING LEG 54
}

\author{
Susan E. Humphris, ${ }^{1}$, Department of Geology, Imperial College, London, SW 7, England \\ and \\ Craig M. Hallman, Scripps Institution of Oceanography, Deep Sea Drilling Project, La Jolla, California
}

\section{INTRODUCTION}

Reactions within biogenic sediments are reflected in the composition of the pore fluids; therefore, analyses of these interstitial solutions give an indication of the nature of diagenetic processes. In an attempt to identify these processes, a program of collection and analysis of interstitial water was planned on Leg 54. In addition to the routine collection of pore waters squeezed from the sediment, this Leg provided an opportunity to test the in situ pore water sampler; its performance is discussed in the next section. Two major procedural problems of pore water collection and analysis were encountered during this cruise. First, the large number of holes that were drilled and the thin regional sediment cover often resulted in only one or two samples from each hole, making interpretation of shipboard data difficult. Secondly, the short duration of drilling at each hole produced a backlog of samples; this meant that many sediment sections were kept for over three days before being squeezed. The effects of this storage were investigated, and the results are discussed in a following section.

\section{Sample Collection}

Interstitial water samples were squeezed at room temperature (varying between 22 and $28^{\circ} \mathrm{C}$ ) from core sections of sediment, using routine shipboard techniques previously described in detail for Leg 23 (Whitmarsh, Weser, et al., 1974). Due to the lack of sediment, these samples were often taken from the mudline core, and from a core just above basement. Where the sediment thickness allowed, samples were spaced at about 20-meter intervals. In addition, a surface sea water sample was taken at each site.

The in situ water sampler was deployed five times, and returned an average of $130 \mathrm{ml}$ of water per run. The operation was timed so that the sampler entered the sediment about 5 minutes prior to the initiation of the sampling mode, and was withdrawn from the sediment about 5 minutes after the sampling mode should have stopped. Sampling time varied from 5 to $7 \frac{1}{2}$ minutes. The mechanics of the instrument proved to be extremely reliable, and water collection by this method is a viable proposition. However, one major question is raised by the collection of over $100 \mathrm{ml}$ of water in only 5 minutes: Is the sample truly one of interstitial water or is the sample con-

\footnotetext{
${ }^{1}$ Present address: Sea Education Association, Woods Hole, Massachusetts.
}

taminated with sea water? During deployment of the sampler, an attempt was made to compensate for the ship's motion by easing the drill pipe down slowly just before, and during, sampling. However, we feel that the sampler must have been subjected to some repositioning, hence destroying the sediment/probe contact and allowing sea water to penetrate into the collection area of the instrument. In the areas that we drilled there was so little downhole variation in the composition of the interstitial waters, and the sediment thickness was so small, that it is difficult to tell whether there was any sea-water contamination. The size of the collected sample would certainly suggest that this was the case, and the reliability of the data collected is open to question. By comparing water collected in situ with detailed squeezed pore water samples in a deep hole where large chemical gradients are expected, any significant sea-water contamination would be identified. Such a test would determine the success of the in situ pore water sampler, and is required before the full potential of this instrument can be realized.

\section{Effects of Storage on Sample Composition}

Owing to the short duration of many of the holes, a backlog of standards and sediment samples built up, many of which were stored at $4^{\circ} \mathrm{C}$ for more than three days before squeezing. Delays in squeezing result in problems of evaporation and re-equilibration of the interstitial water with the sediment.

An experiment was therefore run on a sample from Site 427 to determine the effects of squeezing, and to elucidate the best way of storing samples when necessary; conditions and results are shown in Table 1. The sample that was analyzed immediately, and those that were

TABLE 1

Effects of Storage and Squeezing Temperature on Chemical Analyses of Pore Waters From Section 427-2-5a

\begin{tabular}{|c|c|c|c|c|c|c|}
\hline Sample Condition & $p \mathrm{H}$ & $\begin{array}{l}\text { Alkalinity } \\
\text { (meq/kg) }\end{array}$ & $\underset{(\%)}{S}$ & \multicolumn{2}{|c|}{ (mmoles/1) } & $\begin{array}{l}\mathrm{Cl}^{-} \\
(\%)\end{array}$ \\
\hline $\begin{array}{l}\text { Sample squeezed and } \\
\text { analyzed immediately }\end{array}$ & 7.489 & 3.621 & 36.3 & 10.719 & 52.287 & 19.173 \\
\hline $\begin{array}{l}\text { Sample squeezed, } \\
\text { stored at room tem- } \\
\text { perature for } 24 \text { hours }\end{array}$ & 7.469 & 3.520 & 36.3 & 10.550 & 52.102 & 19.173 \\
\hline $\begin{array}{l}\text { Sample squeezed, } \\
\text { stored at } 4^{\circ} \mathrm{C} \text { for } \\
5 \text { days }\end{array}$ & 7.425 & 3.622 & 36.3 & 10.550 & 51.815 & 19.173 \\
\hline $\begin{array}{l}\text { Sediment stored at } \\
4^{\circ} \mathrm{C} \text { for } 5 \text { days, and } \\
\text { then squeezed }\end{array}$ & 7.634 & 2.872 & 36.0 & 9.936 & 51.783 & 19.207 \\
\hline
\end{tabular}

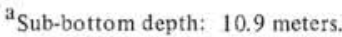


squeezed and stored for up to five days, showed only slight differences in composition. However, considerable differences are observed when sediment is stored for several days before squeezing, particularly in alkalinity and $\mathrm{Ca}^{+2}$ content. This suggests that, if it is necessary to store samples, squeezing should be done immediately upon sediment recovery. The pore waters may then be stored in sealed ampoules without appreciable effects on their composition for several days. The effects of sediment storage before squeezing are particularly evident in the low alkalinity values obtained during the Leg. We therefore recommend that on future Legs a policy of immediate squeezing should be adopted for interstitial water sampling.

\section{Chemical Methods}

Onboard analytical methods and their accuracies have been discussed in a previous volume of the Initial Reports (Gieskes, 1974). Analyses were made of salinity (Goldberg refractometer), alkalinity (potentiometric titration), $p \mathrm{H}, \mathrm{Ca}^{+2}$ (complexometric titration with EGTA), $\mathrm{Mg}^{+2}$ (EDTA titration for alkaline earths), and $\mathrm{Cl}^{-}$(titration with $\mathrm{AgNO}_{3}$, with $\mathrm{K}_{2} \mathrm{CrO}_{4}$ as indicator). The sequence of analyses employed on Leg 54 resulted in alkalinity being the last parameter to be measured. This component depends on very rapid re-equilibration processes. Thus, the alkalinity values would be more representative if they were determined, preferably immediately upon retrieval of the sediment sample, or as the first analysis on opening the sealed ampoule of pore water.

Copenhagen IAPSO standard sea water was used as the standard for each site; the results are presented in Table 2 . The analyses were extremely consistent throughout the cruise for all the variables, except salinity. The high salinity values of $36.0 \%$ obtained at Sites 424 and 425 were originally thought to be due either to contamination or to evaporation of the standard. A new vial of IAPSO standard sea water was therefore opened for Site 427. Again, a high salinity value of $36.3 \%$ was obtained, suggesting that the refractometer was misaligned. However, this was at the start of the storage effect test. Therefore, rather than attempt a recalibration and delay the analy-

TABLE 2

Analyses of IAPSO Standard Sea Water, All Sites

\begin{tabular}{|c|c|c|c|c|c|c|c|}
\hline $\begin{array}{l}\dot{0} \\
z \\
8 \\
\text { J } \\
\text { J } \\
\text { J } \\
\tilde{W}\end{array}$ & Site & $p \mathrm{H}$ & $\begin{array}{c}\mathrm{A}_{\mathrm{t}} \\
(\mathrm{meq} / \\
\mathrm{kg})\end{array}$ & $\underset{(\%)}{S}$ & $\begin{array}{r}\mathrm{Ca}^{+2} \\
\quad(\mathrm{~mm}\end{array}$ & $\begin{array}{l}\mathrm{Mg}+2 \\
\text { les/1) }\end{array}$ & $\begin{array}{l}\mathrm{Cl}^{-} \\
(\% \circ)\end{array}$ \\
\hline 1 & 419 & 7.716 & 2.408 & 35.2 & 10.550 & 53.990 & 19.375 \\
\hline 2 & 420 & 7.738 & 2.360 & 35.2 & 10.550 & 53.990 & 19.375 \\
\hline 3 & 421 & 7.792 & 2.379 & 35.2 & 10.550 & 53.990 & 19.375 \\
\hline 4 & 422 & 7.825 & 2.391 & 35.2 & 10.550 & 53.990 & 19.375 \\
\hline 5 & 423 & 7.789 & 2.376 & 35.2 & 10.550 & 53.990 & 19.375 \\
\hline 6 & 424 & 7.855 & 2.387 & 36.0 & 10.550 & 53.990 & 19.375 \\
\hline 7 & 425 & 7.886 & 2.380 & 36.0 & 10.550 & 53.990 & 19.375 \\
\hline 8 & 427 & 7.944 & 2.405 & 36.3 & 10.550 & 53.990 & 19.375 \\
\hline 9 & 427 & 7.826 & 2.397 & 36.3 & 10.550 & 53.990 & 19.375 \\
\hline 10 & 427 & 7.826 & 2.397 & 36.3 & 10.550 & 53.990 & 19.375 \\
\hline 11 & 428 & 7.826 & 2.397 & 36.3 & 10.550 & 53.990 & 19.375 \\
\hline 12 & 429 & 7.826 & 2.397 & 36.3 & 10.550 & 53.990 & 19.375 \\
\hline
\end{tabular}

ses, we decided to use the refractometer so the results for the test would be internally consistent, although not accurate.

The data are presented in the following two sections for the EPR and Galapagos areas. We should point out, however, that we have some reservations about the validity of the in situ pore water data. The additional problems of storage and squeezing should be borne in mind when evaluating the interstitial water analyses.

\section{EAST PACIFIC RISE (EPR) DATA}

In a previous Leg, a series of DSDP sites ( 69 through 75 ) across the equatorial productivity belt of the East Pacific indicated that the accumulation rate has a considerable influence on the rate and degree of alteration of biogenic oozes and compositional changes in the interstitial water.

Of the eight holes from which sediments were successfully cored in the EPR region at $9^{\circ} \mathrm{N}$, one was located in the Siqueiros fracture zone (Site 427), two in the moat surrounding the OCP Ridge (Sites 422 and 428), and the other five in "normal" EPR crust (Figure 1). All of them were composed of biogenic sediments, principally foraminifer-nannofossil oozes, with layers of siliceous nannofossil ooze. Typical sediment accumulation rates for these holes are $1.7-13 \mathrm{~cm} / 1000$ y (see Site Report). Shipboard analyses of the interstitial water are presented in Table 3.

\section{Site 419}

One squeezed sample and one in situ pore water sample were recovered from this site, in which the sediment was highly disturbed. The low $p \mathrm{H}$ value obtained for Section 419A-2-2 may be an artifact of squeezing (Fanning and Pilson, 1971). This specimen also has a low alkalinity value, which again may be due to the sampling procedure.

\section{Site 420}

Nine samples, three of which were in situ, were collected down to a sub-bottom depth of 116.5 meters (basement was reached at $118 \mathrm{~m}$ ). The variables are plotted against depth in Figure 2. Comparison of the in situ data with the squeezed pore water data indicates reasonable agreement for $\mathrm{Cl}^{-}, p \mathrm{H}$, and $\mathrm{Ca}^{+2}$ and $\mathrm{Mg}^{+2}$ concentrations. The salinity value for the shallow in situ sample is high compared with the $\mathrm{Cl}^{-}$concentrations, and suggests this may be an incorrect reading. The major discrepancies between the two data sets occur in the alkalinity analyses. The squeezed pore waters give consistently lower values than the in situ samples, as was observed in Hole 419. This is probably the result of storage and sample processing techniques, as discussed in the Introduction. In general, the interstitial waters appear constant in composition downhole, indicating that few diagenetic reactions are taking place in the biogenic sediments.

\section{Sites 421, 422, 423, 427, 428, and 429}

Because of the thin sediment cover at most of these sites, pore water samples were taken only from a mud- 


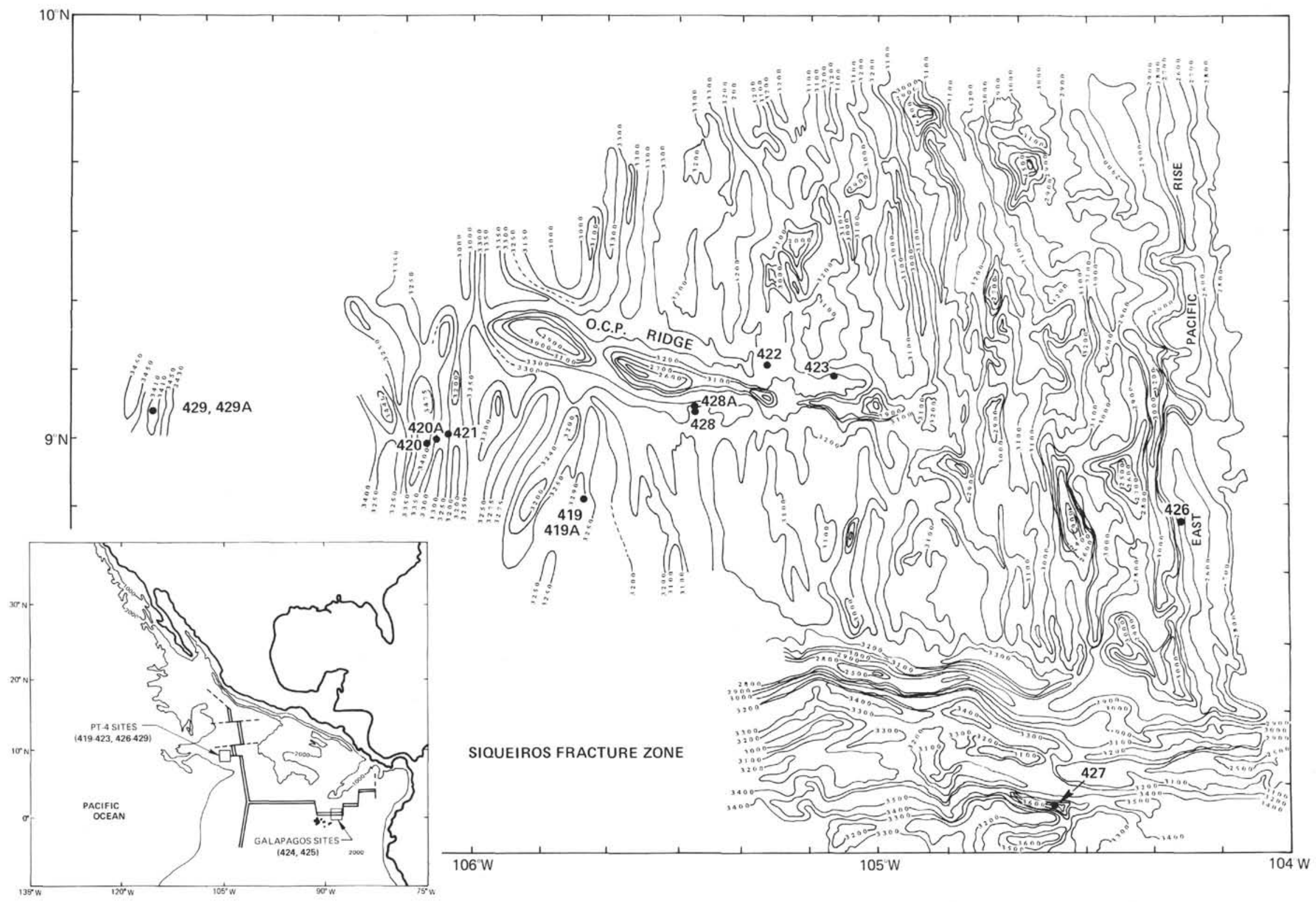

Figure 1. Location of sites drilled during Leg 54. Bathymetry of the East Pacific Rise near the Siqueiros fracture zone from Rosendahl et al. (this volume). 
TABLE 3

Shipboard Interstitial Water Data, East Pacific Rise Sites

\begin{tabular}{|c|c|c|c|c|c|c|c|c|c|}
\hline & $\begin{array}{l}\text { Sub-Bottom } \\
\text { Depth } \\
\text { (m) }\end{array}$ & $p \mathrm{H}$ & $\begin{array}{l}\text { Alkalinity } \\
\text { (meq/kg) }\end{array}$ & $\begin{array}{c}S \\
(\%)\end{array}$ & $\begin{array}{l}\mathrm{Ca}^{+2} \\
\quad(\mathrm{mmol}\end{array}$ & $\begin{array}{l}\mathrm{Mg}^{+2} \\
\mathrm{es} / 1)\end{array}$ & $\begin{array}{l}\mathrm{Cl}- \\
(\% \circ)\end{array}$ & Sediment Type & $\begin{array}{c}\text { Drilling } \\
\text { Disturbance }\end{array}$ \\
\hline \multicolumn{10}{|l|}{ Site 419} \\
\hline Surface sea water & - & 8.059 & 2.298 & 34.1 & 10.075 & 51.982 & 19.945 & & \\
\hline Section 419A-2-2 & 11.9 & 7.845 & 1.500 & 35.5 & 9.313 & 51.031 & 20.824 & $\begin{array}{l}\text { Marly foraminifer- } \\
\text { nannofossil ooze }\end{array}$ & Intense \\
\hline In situ sample 1 & 29.0 & 7.985 & - & 35.5 & 8.429 & 55.343 & 20.314 & $\begin{array}{l}\text { Marly foraminifer- } \\
\text { nannofossil ooze }\end{array}$ & Intense \\
\hline \multicolumn{10}{|l|}{ Site 420} \\
\hline Surface sea water & - & 8.078 & 2.185 & 34.1 & 9.936 & 51.472 & 18.737 & & \\
\hline Section $420-2-2$ & 7.5 & 7.879 & 2.971 & 35.2 & 10.169 & 51.121 & 19.106 & $\begin{array}{l}\text { Foraminifer- } \\
\text { nannofossil ooze }\end{array}$ & Moderate \\
\hline In situ sample 2 & 23.5 & 7.660 & 3.561 & 37.1 & 10.826 & 54.187 & 19.577 & $\begin{array}{l}\text { Siliceous nanno- } \\
\text { fossil ooze }\end{array}$ & Moderate \\
\hline Section 420-6-2 & 45.5 & 7.846 & 2.309 & 36.3 & 9.533 & 52.407 & 19.409 & Nannofossil ooze & Soupy \\
\hline In situ sample 3 & 71.0 & 8.051 & 3.893 & 36.6 & 10.995 & 53.309 & 19.342 & $\begin{array}{l}\text { Siliceous nanno- } \\
\text { fossil ooze }\end{array}$ & Intense \\
\hline Section $420-9-2$ & 72.6 & 7.900 & 2.386 & 36.3 & 10.275 & 52.256 & 19.543 & $\begin{array}{l}\text { Siliceous nanno- } \\
\text { fossil ooze }\end{array}$ & Moderate \\
\hline Section 420-11-4 & 95.1 & 7.961 & 1.301 & 36.3 & 8.940 & 52.823 & 19.610 & Nannofossil ooze & Moderate \\
\hline In situ sample 4 & 99.5 & 8.419 & 2.685 & 36.0 & 9.597 & 52.993 & 19.241 & Nannofossil ooze & Moderate \\
\hline Section 420-12-1 & 101.0 & 8.163 & 1.370 & 36.3 & 9.385 & 52.496 & 19.610 & Nannofossil ooze & Moderate \\
\hline Section 420-13-5 & 116.5 & 8.453 & 1.091 & 35.8 & 9.088 & 51.493 & 19.509 & Nannofossil ooze & Moderate \\
\hline \multicolumn{10}{|l|}{ Site 421} \\
\hline Surface sea water & - & 8.048 & 2.218 & 34.9 & 10.126 & 52.109 & 18.701 & & \\
\hline Section 421-1-4 & 6.0 & 7.843 & 2.391 & 36.0 & 9.872 & 51.476 & 19.173 & $\begin{array}{l}\text { Foraminifer- } \\
\text { nannofossil ooze }\end{array}$ & Moderate \\
\hline \multicolumn{10}{|l|}{ Site 422} \\
\hline Surface sea water & - & 8.114 & 2.209 & 34.6 & 10.105 & 51.132 & 18.533 & & \\
\hline Section 422-1-3 & 4.5 & 7.868 & 2.859 & 36.0 & 10.126 & 50.757 & 19.308 & $\begin{array}{l}\text { Nannofossil- } \\
\text { foraminiferal ooze }\end{array}$ & Moderate \\
\hline Section 422-8-1 & 50.5 & 7.953 & 2.243 & 36.0 & 9.830 & 51.879 & 19.443 & $\begin{array}{l}\text { Foraminifer- } \\
\text { nannofossil ooze }\end{array}$ & Intense \\
\hline \multicolumn{10}{|l|}{ Site 423} \\
\hline Surface sea water & - & 8.083 & 2.168 & 34.6 & 10.185 & 51.641 & 18.565 & & \\
\hline Section 423-1-2 & 3.0 & 7.640 & 2.967 & 36.0 & 10.571 & 50.666 & 19.206 & $\begin{array}{l}\text { Brown calcareous } \\
\text { clay }\end{array}$ & Moderate \\
\hline Section 423-5-2 & 35.5 & 7.990 & 2.166 & 36.0 & 9.971 & 51.148 & 19.139 & Nannofossil ooze & Moderate \\
\hline \multicolumn{10}{|l|}{ Site 427} \\
\hline Surface sea water & - & 8.141 & 2.192 & 35.2 & 10.020 & 51.511 & 18.601 & & \\
\hline Section 427-2-5 & 10.9 & 7.489 & 3.621 & 36.3 & 10.719 & 52.287 & 19.173 & $\begin{array}{l}\text { Marly foraminifer- } \\
\text { nannofossil ooze }\end{array}$ & Moderate \\
\hline Section $427-7-3$ & 93.5 & 7.657 & 3.172 & 36.8 & 11.122 & 52.948 & 19.678 & $\begin{array}{l}\text { Siliceous nanno- } \\
\text { fossil ooze }\end{array}$ & Intense \\
\hline \multicolumn{10}{|l|}{ Site 428} \\
\hline Surface sea water & - & 8.080 & 2.205 & 35.2 & 9.914 & 51.099 & 18.563 & & \\
\hline Section 428-2-3 & 33.5 & 7.916 & 1.813 & 36.3 & 9.427 & 51.469 & 19.173 & $\begin{array}{l}\text { Marly foraminifer- } \\
\text { nannofossil ooze }\end{array}$ & Intense \\
\hline Section $428-5-2$ & 60.5 & 8.162 & 1.221 & 36.3 & 8.686 & 51.662 & 19.409 & $\begin{array}{l}\text { Marly foraminifer- } \\
\text { nannofossil ooze }\end{array}$ & Moderate \\
\hline \multicolumn{10}{|l|}{ Site 429} \\
\hline Surface sea water & - & 8.119 & 2.218 & 34.9 & 9.914 & 51.099 & 18.601 & & \\
\hline Section 429-1-3 & 3.06 & 7.444 & 2.555 & 36.3 & 10.381 & 51.925 & 19.375 & Nannofossil ooze & Moderate \\
\hline
\end{tabular}




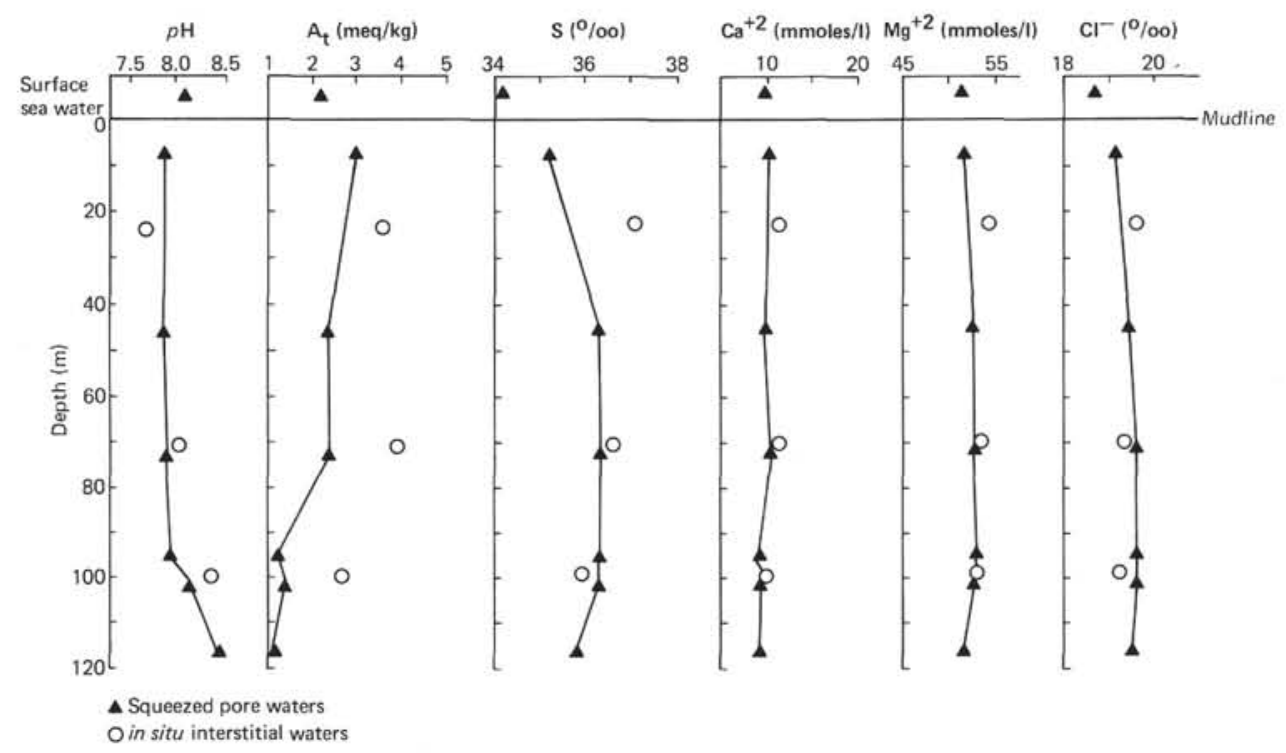

Figure 2. Chemistry of interstitial waters versus depth, Site 420.

line core and a core near the basement. This makes interpretation of any downhole chemical gradients very difficult.

Sites 423, 421, and 429 were located about 99, 201, and $264 \mathrm{~km}$ respectively, west of the EPR. Holes 421 and 429 were washed down to basement after taking a mudline core; hence, only one squeezed pore water sample could be taken from each. Hole 423 was continuously cored through 38 meters of sediment, so two squeezed samples were taken-one from the mudline core, and one just above the basement. Section 423-1-2 was taken from a brown calcareous clay, while Section 423-5-2 was taken from a nannofossil ooze. Compared with the overlying sea water, the pore water from the brown clay contains a higher concentration of $\mathrm{Ca}^{+2}$ and has increased alkalinity, but a lower $\mathrm{Mg}^{+2}$ content. The pore water from the biogenic ooze is similar in composition to the overlying sea water. This may be an indication of diagenetic reactions in the brown clay layer, but no conclusions can be drawn from the analysis of only one sample.

Site 422 was located in the northern moat of the OCP Ridge. The sediment was continuously cored to basement, and another 4 meters of foraminifer-nannofossil ooze was found between two doleritic units. Squeezed samples were taken from the mudline core and the sediment layer between the basement units. Both samples are similar in composition to the overlying sea water, suggesting few diagenetic reactions within these sediments.

Site 428 was located immediately south of the OCP Ridge on the transition zone between it and the EPR fabric; coring proceeded continuously through $61 \mathrm{me}$ ters of sediment. Two squeezed pore water samples were taken from sub-bottom depths of 33.5 and 60.5 meters. The sediments consisted of marly foraminifer-nannofossil ooze that had been highly disturbed by drilling. These samples were stored for two to three days before analysis; thus, anomalously low alkalinity values were determined. There is indication of a decrease in $\mathrm{Ca}^{+2}$ content and an increase in $\mathrm{Mg}^{+2}$ concentration with depth, but interpretation is not possible on the basis of only two samples.

Site 427 was drilled in the deepest known trough in the Siqueiros fracture zone, but the 146 meters of sediment was only spot-cored. At this site, one $14-\mathrm{cm} \mathrm{sec-}$ tion of sediment was taken for the storage tests described in the Introduction. One additional squeezed pore water sample was taken from 93.5 meters. The downhole data show only minor variations in the chemical composition of the pore waters, indicating that there are few diagenetic processes in these sediments.

Overall, the available interstitial water data from the holes drilled in the EPR area suggest that there is very little variation in the composition of the pore waters. This indicates that diagenetic processes in this area are not well advanced. This is in agreement with Manheim and Sayles (1974), who have observed that some biogenic oozes that retain a high water content show very little evidence of diagenesis and alteration, and exhibit little change in pore fluid composition.

\section{GALAPAGOS AREA DATA}

Two sites were occupied in the Galapagos area (Figure 1). Holes 424, 424A, 424B, and 424C constituted a north-south transect spanning about 20,000 y. in the mounds hydrothermal area south of the Galapagos Spreading Center. In this area, we hoped that some variation in the chemistry of the interstitial waters would be observed owing to the presence of hydrothermal sediments in sections of these holes. Site 425 was located about $62 \mathrm{~km}$ north of the Galapagos Spreading Center in an area characterized by high heat flow, and it was only spot-cored. Sediment accumulation rates were about 3-5 cm/1000 y., and the cores recovered from each were moderately to highly disturbed (see Site Report). The shipboard analyses of the interstitial waters are presented in Table 4. 
TABLE 4

Shipboard Interstitial Water Data Galapagos Sites

\begin{tabular}{|c|c|c|c|c|c|c|c|c|c|}
\hline & $\begin{array}{l}\text { Sub-Bottom } \\
\text { Depth } \\
\text { (m) }\end{array}$ & $p \mathrm{H}$ & $\begin{array}{l}\text { Alkalinity } \\
(\mathrm{meq} / \mathrm{kg})\end{array}$ & $\underset{(\% \circ)}{S}$ & $\begin{array}{l}\mathrm{Ca}^{+2} \\
\quad(\mathrm{mmo}\end{array}$ & $\begin{array}{l}\mathrm{Mg}^{+2} \\
\text { les } / 1)\end{array}$ & $\begin{array}{l}\left.\mathrm{Cl}^{-}\right) \\
(\% \circ)\end{array}$ & Sediment Type & $\begin{array}{c}\text { Drilling } \\
\text { Disturbance }\end{array}$ \\
\hline \multicolumn{10}{|l|}{ Site 424} \\
\hline Surface sea water & - & 7.848 & 2.309 & 36.3 & 10.529 & 54.011 & 19.409 & & \\
\hline Section $424-3-6$ & 28.45 & 7.758 & 1.998 & 36.0 & 11.532 & 50.530 & 19.341 & $\begin{array}{l}\text { Foraminifer- } \\
\text { nannofossil ooze }\end{array}$ & Moderate \\
\hline In situ sample 5 & 28.5 & 7.847 & 2.418 & 35.2 & 12.280 & 50.785 & 18.937 & $\begin{array}{l}\text { Foraminifer- } \\
\text { nannofossil ooze }\end{array}$ & Moderate \\
\hline Section $424-4-4$ & 34.5 & 7.586 & 2.113 & 35.2 & 11.895 & 51.465 & 19.274 & $\begin{array}{l}\text { Foraminifer- } \\
\text { nannofossil ooze }\end{array}$ & Intense \\
\hline Section $424 A-2-2$ & 17.95 & 7.688 & 1.797 & 35.8 & 11.490 & 51.457 & 19.274 & $\begin{array}{l}\text { Foraminifer- } \\
\text { nannofossil ooze }\end{array}$ & Intense \\
\hline Section 424B-3-4 & 19.0 & 8.074 & 1.080 & 35.8 & 10.849 & 50.918 & 19.207 & $\begin{array}{l}\text { Foraminifer- } \\
\text { nannofossil ooze }\end{array}$ & Moderate \\
\hline \multicolumn{10}{|l|}{ Site 425} \\
\hline Surface sea water & - & 8.113 & 2.119 & 34.1 & 9.888 & 51.113 & 18.302 & & \\
\hline Section $425-3-2$ & 26.5 & 7.602 & 2.843 & 36.0 & 11.233 & 50.948 & 19.241 & $\begin{array}{l}\text { Siliceous } \\
\text { nannofossil ooze }\end{array}$ & Intense \\
\hline Section $425-5-2$ & 64.5 & 7.465 & 2.031 & 36.8 & 15.355 & 48.891 & 19.643 & $\begin{array}{l}\text { Foraminifer- } \\
\text { nannofossil ooze }\end{array}$ & Intense \\
\hline
\end{tabular}

\section{Site 424}

Four holes were drilled at this site and they have generally similar lithological characteristics. Hole 424 was situated close to the top of a mound and was continuously cored through 31 meters of sediment. The in situ sampler was deployed once, and the sample collected from 2.5 meters above basement. Hole 424A was also positioned on a mound and was continuously cored through 29 meters of sediment, although only 13 meters was recovered. Hole 424B was positioned away from the mounds in order to establish an areal reference section; it was continuously cored. Hole $424 C$ was drilled nearby through 31 meters of sediment by alternately coring and washing; therefore, no pore water sample was obtained from this hole.

The data are all plotted versus depth in Figure 3. The analyses of the in situ sample and the adjacent squeezed sample agree well, except for salinity. In general, there does not appear to be any difference between the samples taken from the mounds area (Holes 424 and 424A), and those away from this area (Hole 424B). The low alkalinities are probably due to storage effects. There is very little evidence for any downhole chemical gradients in these sediments. In addition, the composition of the samples is very similar to that of the overlying sea water. This is rather surprising, especially from the cores that contain sections of hydrothermal sediments of an entirely different composition from that of the biogenic oozes, and may be an indication of sea-water contamination.

\section{Site $\mathbf{4 2 5}$}

Two squeezed pore water samples, from sub-bottom depths of 26.5 and 64.5 meters, plus a surface sea water sample, were taken at Site 425 . The sediments at this site were soupy and deformed; they contained thin layers of hydrotroilite, suggesting that some reactions due to reducing conditions were occurring. On the basis of only two analyses, it is not possible to determine the reactions that are taking place. However, there do appear to be chemical variations in the fluid. The $\mathrm{Ca}^{+2}$ content increases, while the concentration of $\mathrm{Mg}^{+2}$ and alkalinity decrease. The changes in the $\mathrm{Mg}$ and $\mathrm{Ca}$ contents do not comprise the 1:1 molar exchange that would be expected from ion exchange in carbonates, the change in the $\mathrm{Ca}^{+2}$ content being larger than that in $\mathrm{Mg}^{+2}$. The slight increase in $\mathrm{Cl}^{-}$and the decrease in alkalinity are also consistent with the contention that reactions are occurring within the sediment. The high salinities obtained were the first indication of the refractometer calibration problem previously discussed, and these results are probably not reliable. The reactions cannot be elucidated on the basis of these data, but the alteration of trace amounts of volcanic glass in the sediments could provide additional fluxes of various ions.

\section{REFERENCES}

Fanning, K. A., and Pilson, M. E. Q., 1971. Interstitial silica and $\mathrm{pH}$ in marine sediments: some effects of sampling procedures, Science, v. 173, p. 1228.

Gieskes, J. M., 1974. Interstitial water studies, Leg 25. In Simpson, E. S. W., Schlich, R., et al., 1974. Initial Reports of the Deep Sea Drilling Project, v. 25: Washington (U.S. Government Printing Office), p. 363.

Manheim, F. T., and Sayles, F. L., 1974. Composition and origin of interstitial waters of marine sediments, based on Deep Sea Drill cores. In Goldberg, E. D. (Ed.), The Sea (v. 5): New York (Wiley Interscience), p. 527.

Whitmarsh, R. B., Weser, O. E., et al., 1974. Initial Reports of the Deep Sea Drilling Project, v. 23: Washington (U.S. Government Printing Office). 


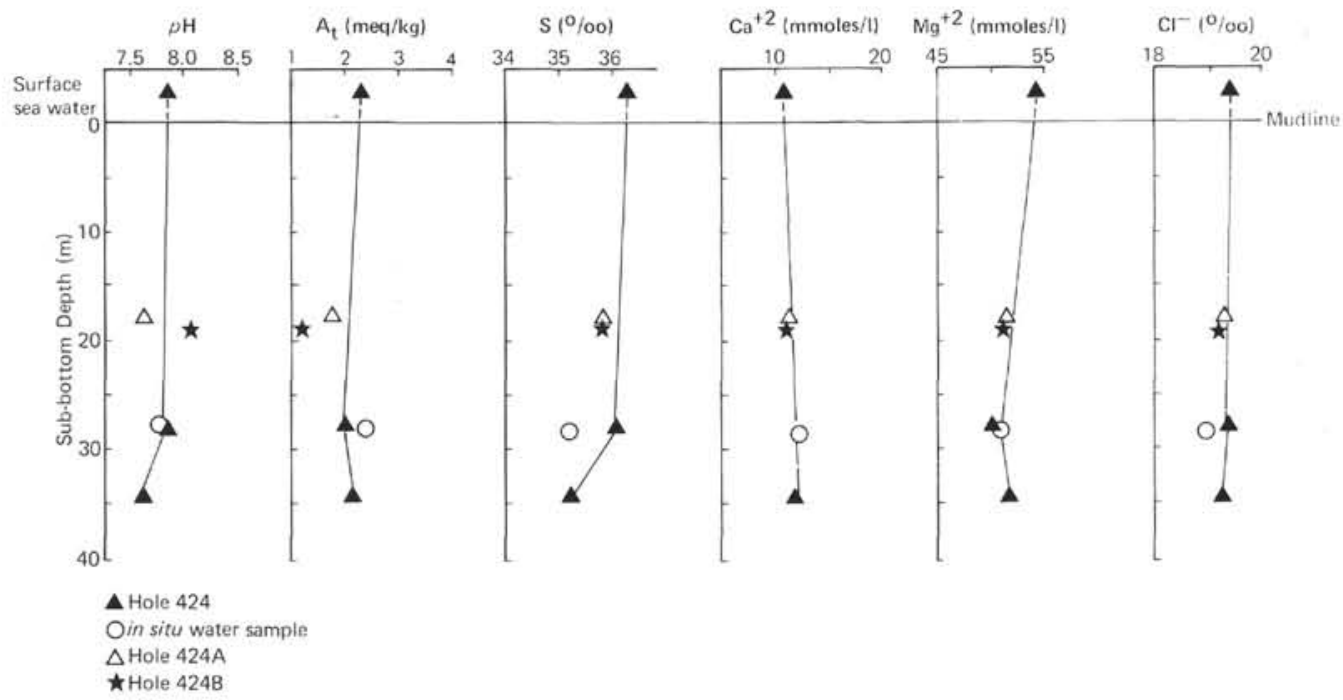

Figure 3. Chemistry of interstitial waters versus depth, Site 424. 